Check for updates

Cite this: Mater. Adv., 2020, 1,1347

Received 12th May 2020, Accepted 9th July 2020

DOI: $10.1039 / \mathrm{d} 0 \mathrm{ma00300j}$

rsc.li/materials-advances

\section{Reversible detection of hypochlorite using the deprotonation-protonation strategy: a search for new building blocks $\dagger$}

\author{
Gurpreet Singh, ${ }^{a}$ Amrit Kaur, ${ }^{a}$ Manik Sharma, ${ }^{a}$ Vandana Bhalla, (D) a Davinder Singh, \\ Saroj Arora ${ }^{b}$ and Manoj Kumar iD *a
}

\begin{abstract}
A variety of building blocks having 'acidic protons' and potential to undergo self-assembly have been synthesized for the reversible detection of hypochlorite in aqueous media using deprotonation-protonation as the detection strategy. Among the synthesized building blocks, AIE active supramolecular assemblies of ESIPT active salicylaldehyde probe 1 having a p $K_{a}$ value of 3.20 exhibit a highly sensitive response towards hypochlorite with a detection limit in the nanomolar range $(50.2 \mathrm{nM})$. The sensitive response of the assemblies towards $\mathrm{ClO}^{-}$is attributed to their high acidity and formation of more ordered assemblies after deprotonation. Other way around, assemblies of indolium probe 5 having a high $\mathrm{p} K_{\mathrm{a}}$ (6.85) value show hypochlorite induced emission enhancement with a detection limit in the micromolar range $(38 \mu \mathrm{M})$. This reasonably good detection limit is attributed to the hypochlorite induced sensitive and sharp emission changes due to the generation of ordered assemblies of deprotonated species. To sum up, the work being presented in this manuscript demonstrates the importance of 'acidic protons' and formation of ordered assemblies of deprotonated species for reversible, colorimetric and fluorogenic detection of hypochlorite using the deprotonation-protonation strategy. Furthermore, the real time application for 'on site' detection of hypochlorite has been demonstrated by using the 'dip strip' prepared from the solution of assemblies of probe 1. Unprecedented, the present study further reveals the potential of ESIPT-AIE active probe $\mathbf{1}$ as an antioxidant for suppressing sodium hypochlorite induced oxidative transformation under lab conditions and protection of cells from hypochlorite induced cell death in L-929 cell lines.
\end{abstract}

\section{Introduction}

Hypochlorite is vital for smooth functioning of numerous biological activities such as cell signalling, regulation of the immune system by providing defence against microorganisms and inflammation, etc. ${ }^{1-3}$ To maintain the demand-supply balance, hypochlorite is endogenously produced. ${ }^{4,5}$ Though the whole process is well regulated, however, a slight over production of hypochlorite may result in the accumulation of $\mathrm{ClO}^{-}$in living systems which eventually generates oxidative stress and hence can cause various neurodegenerative and cardiovascular diseases and cancer. ${ }^{6-8}$ Over the last few years, a variety of reaction-based fluorescent probes involving irreversible

\footnotetext{
${ }^{a}$ Department of Chemistry, UGC Sponsored Centre for Advanced Studies-II, Guru Nanak Dev University, Amritsar 143005, Punjab, India. E-mail:mksharmaa@yahoo.co.in

${ }^{b}$ Department of Botanical and Environmental Sciences, Guru Nanak Dev University, Amritsar 143005, Punjab, India

$\dagger$ Electronic supplementary information (ESI) available: Experimental details, photophysical studies, cell imaging, and NMR, ESI-MS and FT-IR spectra. See DOI: $10.1039 / \mathrm{d} 0 \mathrm{ma} 00300 \mathrm{j}$
}

changes around carbon-carbon, ${ }^{9-14}$ carbon-nitrogen, ${ }^{15,16}$ carbonsulphur, ${ }^{17,18}$ and carbon-oxygen ${ }^{19}$ bonds have been reported for the detection of hypochlorite (Table S1, ESI $\dagger$ ). The reaction-based strategy is efficient but hypochlorite induced irreversible chemical changes are introduced in the probe as a result of which the probe is rendered useless after its first application. The development of reversible probes for the detection of hypochlorite is an important contribution towards sustainable chemistry as it significantly affects the economics of the molecular recognition process. Furthermore, reversible fluorescent probes are also suitable for visualizing redox stress and continuous monitoring of real-time sensing of hypochlorite. In this direction, several redox active probes have been developed for reversible detection of hypochlorite; however, the tedious synthesis process, low sensitivity, longer response time and small Stokes shift restricted the real time applications of these probes. ${ }^{20-22}$

Recently, we reported ${ }^{23}$ a dimethylaminocinnamaldehyde linked oxime based chemodosimeter for the detection of hypochlorite. The chemodosimeter undergoes fluorescence enhancement in the presence of hypochlorite due to the irreversible conversion of the oxime unit into nitrile oxide. In continuation 
of this work and motivated by the merits of reversible probes, we were then interested in the development of a reversible 'turn on' fluorescent probe for the detection of $\mathrm{ClO}^{-}$. Keeping in mind the weak basic nature of hypochlorite $\left(\mathrm{p} K_{\mathrm{a}}=7.40\right),{ }^{24}$ we planned to utilize the deprotonation-protonation strategy for detecting the hypochlorite induced emission changes. We envisaged that a probe having labile protons may have potential to exist in optically switchable protonated-deprotonated states in the presence of hypochlorite. Salicylaldehyde azine derivatives are known to exist in tautomeric forms (keto/ enol) via excited state intramolecular proton transfer (ESIPT). We envisaged that by incorporating appropriate fluorophores, the keto-enol tautomerism may be tuned to achieve hypochlorite induced photophysical changes. Keeping in mind the good photophysical properties and electron deficient nature of indole derivatives, ${ }^{25}$ in the present study, we explored the potential of indole-SAA derivatives as hypochlorite sensing building blocks. For the detection of hypochlorite in aqueous media, it is very important to get rid of the analyte $\left(\mathrm{ClO}^{-}\right)-$ solvent $\left(\mathrm{H}_{2} \mathrm{O}\right)$ interactions. We expected that by the introduction of multiple 'acidic protons' in the sensing platform the problems due to hypochlorite solvation could be overcome. Our experience in the field of development of aggregation induced emission materials encouraged us to explore the potential of the AIE phenomenon in generating assemblies of the designed molecule having multiple 'acidic protons'. Thus, we synthesized probe 1 by covalently linking SAA units to electron deficient azaindole units and introduced free rotating $\mathrm{C}-\mathrm{C} / \mathrm{C}-\mathrm{N}$ bonds in the molecule. Probe 1 exhibits ESIPT and AIE characteristics in the mixed aqueous medium and the $\mathrm{p} K_{\mathrm{a}}$ value of assemblies was found to be 3.20. To our pleasure, the enolic assemblies of probe 1 having 'acidic protons' show strong fluorogenic and fully reversible responses towards $\mathrm{ClO}^{-}$with a detection limit in the range of $50.2 \mathrm{nM}$. To the best of our knowledge, this is the first report of ESIPT-AIE active materials for 'turn on' detection of hypochlorite. Furthermore, the fluorogenic response was also accompanied by colorimetric changes which are clearly visible to the naked eye. The probes showing a colorimetric response have an added advantage of signalling the presence of analytes without the need for any instrument. Most of the reported reaction-based probes exhibit fluorogenic responses only and the sensing event is not visible to the naked eye (Table S1, ESI $\dagger$ ). To understand the importance of 'acidic protons'/AIE phenomena in reversible 'turn on' detection of hypochlorite, we also synthesized AIE inactive indolium based probe 5 . Despite their two-fold high $\mathrm{p} K_{\mathrm{a}}$ value (6.85), assemblies of indolium based probe 5 exhibit excellent hypochlorite induced emission enhancement due to the formation of closely packed assemblies of deprotonated species. Thus, the present study reveals the importance of ordered aggregation of deprotonated molecules after the sensing event along with the acidic strength of parent protonated species for sensitive, colorimetric and fluorogenic detection of hypochlorite in aqueous media. Furthermore, the assemblies of probe $\mathbf{1}$ exhibit strong antioxidant potential for suppressing the sodium hypochlorite induced oxidative transformation of benzylamine under lab conditions. Although the applications of a variety of probes have been demonstrated for organelle target ${ }^{11,14}$ cell imaging (Table S1, $\mathrm{ESI}_{\dagger}^{\dagger}$ ), the potential of none of these probes has been explored as an antioxidant for protection against hypochlorite induced oxidative stress. In this context, unprecedented, the work being presented in this manuscript demonstrates the potential of the assemblies of $\mathbf{1}$ to protect the living cells from hypochlorite induced cytotoxicity.

\section{Results and discussion}

Probe 1 (Chart 1 ) was obtained in $85 \%$ yield by condensation of 7-azaindole-3-carboxaldehyde and salicylaldehyde hydrazone in EtOH:DCM $(8: 2, \mathrm{v} / \mathrm{v})$. The structure of compound 1 was confirmed from its spectroscopic data (Fig. S39-S41, ESI $\dagger$ ).

The photophysical properties of probe 1 were investigated by UV-vis and fluorescence spectroscopic techniques. The UV-vis spectrum of probe $\mathbf{1}(5.0 \mu \mathrm{M})$ in DMSO exhibits two absorption bands at 290 and $350 \mathrm{~nm}$ due to the $\pi-\pi^{*}$ and $\mathrm{n}-\pi^{*}$ transitions, respectively. On increasing the water fraction up to $100 \%$ in solution of probe $\mathbf{1}$ (15.0 $\mu \mathrm{l}$ of $10^{-3} \mathrm{M}$ stock solution in DMSO), the intensity of the absorption band at $350 \mathrm{~nm}$ decreases and the band is blue-shifted $(\sim 7 \mathrm{~nm})$ to $343 \mathrm{~nm}$ (Fig. S1, ESI $\dagger$ ). Furthermore, the level-off tail appears in the visible region (400-550 nm) which indicates the formation of aggregates of probe 1. The solvent dependent studies further support the presence of ESIPT in probe 1 (Fig. S2, ESI $\dagger$ ). The fluorescence spectrum of probe $1(5.0 \mu \mathrm{M})$ in DMSO exhibits a strong emission band at $435 \mathrm{~nm}(\phi=0.15)$ and a very weak emission band at $530 \mathrm{~nm}(\phi=0.008)$ when excited at $350 \mathrm{~nm}$ (Fig. S3, ESI $\dagger$ ). The band at $435 \mathrm{~nm}$ is attributed to the 1-enol form (Scheme 1) and the band at longer wavelength $530 \mathrm{~nm}$ is attributed to the 1-keto form (Scheme 1) of probe 1. To confirm the ESIPT behaviour of probe 1, we synthesized a model compound 2 (Chart 1) which lacked in the phenolic group. Model compound 2 did not show any emission at longer wavelength in DMSO or in mixed aqueous media which confirms that the emission band at longer wavelength $530 \mathrm{~nm}$ in probe $\mathbf{1}$ is due to the keto form as a result of the

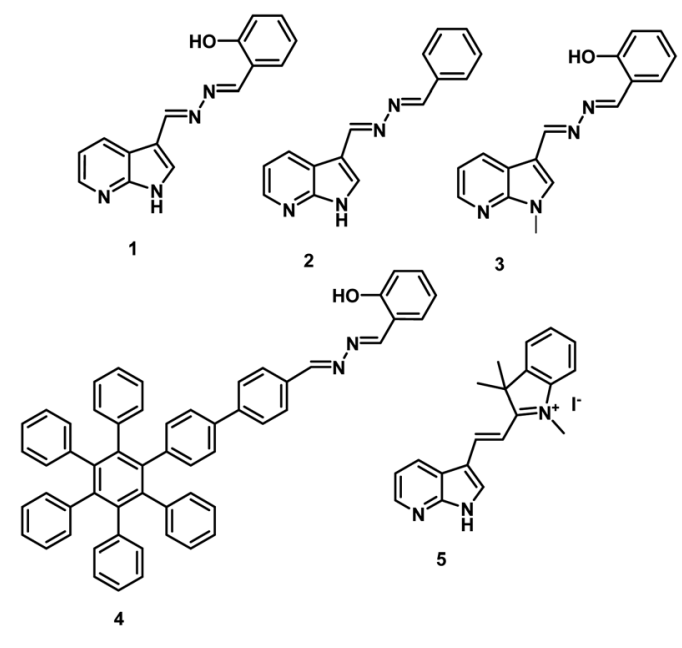

Chart 1 Structures of probes 1, 2, 3, 4 and $\mathbf{5}$. 


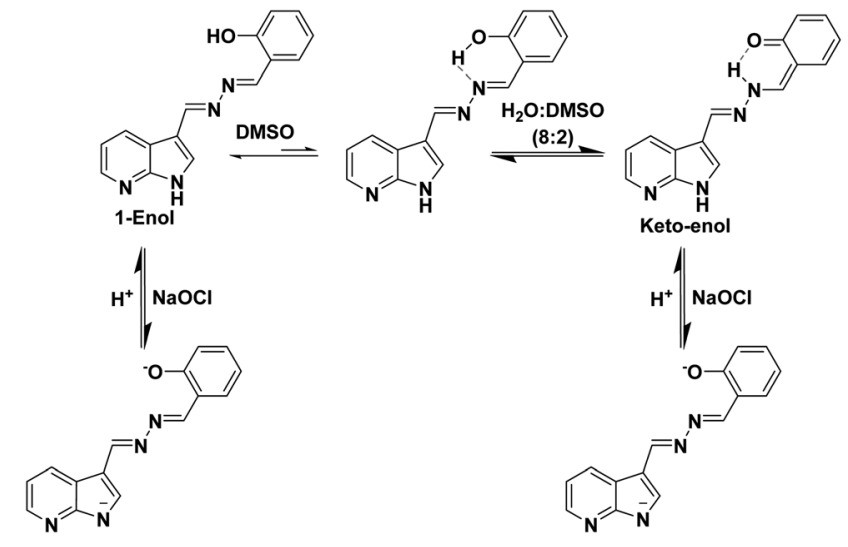

Scheme 1 Sensing mechanism of probe 1 towards hypochlorite.

ESIPT phenomenon (Fig. S4, ESI $\dagger$ ). The low intensity of the ESIPT band of probe 1 may be attributed to the high polarity of DMSO. Upon introducing $\mathrm{H}_{2} \mathrm{O}$ as the co-solvent in DMSO up to $80 \%$, probe 1 shows an increase in the emission intensity of the band at $530 \mathrm{~nm}$ and a decrease in the emission intensity of band at $435 \mathrm{~nm}$. Interestingly, upon further increasing the water fraction up to $100 \%(15.0 \mu \mathrm{l}$ of stock solution in DMSO), the emission intensity of the band centred at $530 \mathrm{~nm}$ is drastically enhanced $(\phi=0.45)$ (Fig. S5, ESI $\dagger$ ) and the emission band at $435 \mathrm{~nm}$ disappears. In solid state, probe 1 exhibits a single emission band at $530 \mathrm{~nm}$ and the spectrum is very similar to that in the aqueous media (Fig. S6, ESI $\dagger$ ). These studies suggest that molecules of probe $\mathbf{1}$ in aqueous media undergo self-assembly and due to the aggregation, intramolecular $\mathrm{H}$-bonding is enhanced which increases the proportion of the keto form of probe 1. The keto-enol tautomerism was further confirmed by solvent dependent FT-IR and ${ }^{1} \mathrm{H}$ NMR studies (Fig. S7-S11, ESI $\dagger$ ). We further believe that a drastic increase in the emission intensity of probe 1 in aqueous media is attributed to the restriction of rotation in mixed aqueous media. The viscosity dependent studies of probe $\mathbf{1}$ in DMSO: glycerol also confirms the AIE characteristics of the probe (Fig. S12, ESI $\dagger$ ). The TEM image of compound 1 in $\mathrm{H}_{2} \mathrm{O} /$ DMSO $(8 / 2)$ mixed aqueous media shows the presence of spherical aggregates having an average size in the range of 150-200 nm (Fig. S13, ESI $\dagger$ ).

Next, we examined the molecular recognition behaviour of probe 1 toward different reactive oxygen species (ROS) and anions using UV-vis and fluorescence spectroscopic techniques. The absorption spectrum of probe $1(5.0 \mu \mathrm{M})$ in PBS/DMSO $(8 / 2, \mathrm{v} / \mathrm{v}, \mathrm{pH}=7.4$. $)$ shows an absorption band at $343 \mathrm{~nm}$ $\left(\varepsilon=6.60 \times 10^{4} \mathrm{M}^{-1} \mathrm{~cm}^{-1}\right)$. Upon addition of $\mathrm{ClO}^{-}$ions $(0-90 \mu \mathrm{M})$, the intensity of the band at $343 \mathrm{~nm}$ decreases $\left(\varepsilon=3.58 \times 10^{4} \mathrm{M}^{-1} \mathrm{~cm}^{-1}\right)$ and a new band appears at $410 \mathrm{~nm}$ $\left(\varepsilon=4.40 \times 10^{4} \mathrm{M}^{-1} \mathrm{~cm}^{-1}\right)$ with an isosbestic point at $370 \mathrm{~nm}$ $\left(\varepsilon=3.14 \times 10^{4} \mathrm{M}^{-1} \mathrm{~cm}^{-1}\right.$ ) (Fig. 1A). The colour of the solution turns yellow from colorless, thus, allowing the colorimetric detection of hypochlorite in mixed aqueous medium by the naked eye (inset, Fig. 1A). The fluorescence spectrum of probe $1(5.0 \mu \mathrm{M})$ in the PBS/DMSO (8/2, v/v) solvent mixture exhibits dual emission

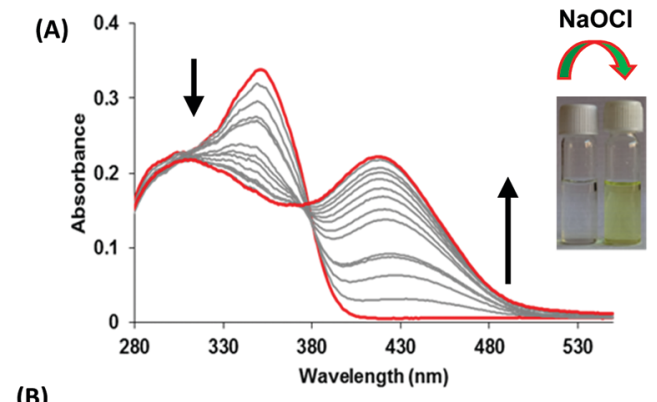

(B)

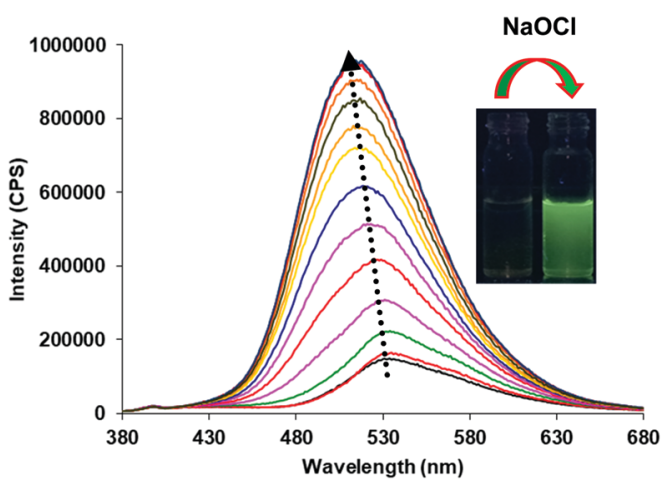

Fig. 1 (A) Absorption and (B) fluorescence emission spectra of probe 1 upon increasing concentration of hypochlorite $(0-90 \mu \mathrm{M})$ in PBS/DMSO $(8 / 2, \mathrm{v} / \mathrm{v})$ mixture, $\mathrm{pH}=7.4 ; \lambda_{\mathrm{ex}}=350 \mathrm{~nm}$.

bands with a maxima at $530 \mathrm{~nm}(\phi=0.05)$ and $435 \mathrm{~nm}(\phi=0.02)$ when excited at $350 \mathrm{~nm}$ (Fig. S14, ESI $\dagger$ ). Upon addition of $\mathrm{ClO}^{-}$ $(0-90 \mu \mathrm{M})$, the band at $530 \mathrm{~nm}$ is blue-shifted to $510 \mathrm{~nm}$ and the emission intensity was enhanced up to around 10-fold ( $\phi=0.48)$ (Fig. 1B). The detection limit of probe $\mathbf{1}$ for $\mathrm{ClO}^{-}$was found to be $50.2 \mathrm{nM}$ (Fig. S15, ESI†). These results indicate that the aggregates of probe 1 can detect hypochlorite with much lower detection limit. However, assemblies of probe 1 in $100 \%$ aqueous media show no absorption and emission changes in the presence of hypochlorite (Fig. S16 and S17, ESI $\dagger$ ). We believe that in $100 \%$ water, assemblies of probe $\mathbf{1}$ mainly exist in keto forms which are not interacting with hypochlorite. The time resolved fluorescence studies of aggregates of probe $\mathbf{1}$ in the absence of $\mathrm{ClO}^{-}$show triexponential decay with an average lifetime of $0.05 \mathrm{~ns}$ in the aggregated state which increases to $0.48 \mathrm{~ns}$ upon addition of $\mathrm{ClO}^{-}$ $(90 \mu \mathrm{M})$ ions (Fig. S18, ESI $\dagger$ ). These studies indicate that assemblies of deprotonated species of probe $\mathbf{1}$ become more ordered and hence show enhanced fluorescence in the presence of $\mathrm{ClO}^{-}$ ions. To check the reversibility of probe $\mathbf{1}$, we performed the reversibility experiment by carrying out the emission studies of probe 1 with $\mathrm{ClO}^{-}$followed by the addition of trifluoroacetic acid (TFA). On controlled addition of $\mathrm{H}^{+}$source (TFA, $90 \mu \mathrm{M}$ ), the emission band at $510 \mathrm{~nm}$ disappears and the original spectrum is restored (Fig. S19, ESI $\dagger$ ). Interestingly, alternate addition of $\mathrm{ClO}^{-}$ and $\mathrm{H}^{+}$gave similar results to those observed in the previous cycle, which proves that $\mathrm{ClO}^{-}$recognition was reversible. The reversibility cycles could be repeated up to five times without any significant change in emission intensity. We also examined the recognition behaviour of probe $\mathbf{1}$ at different $\mathrm{pH}$ values towards hypochlorite. The assemblies of probe $\mathbf{1}$ show emission 

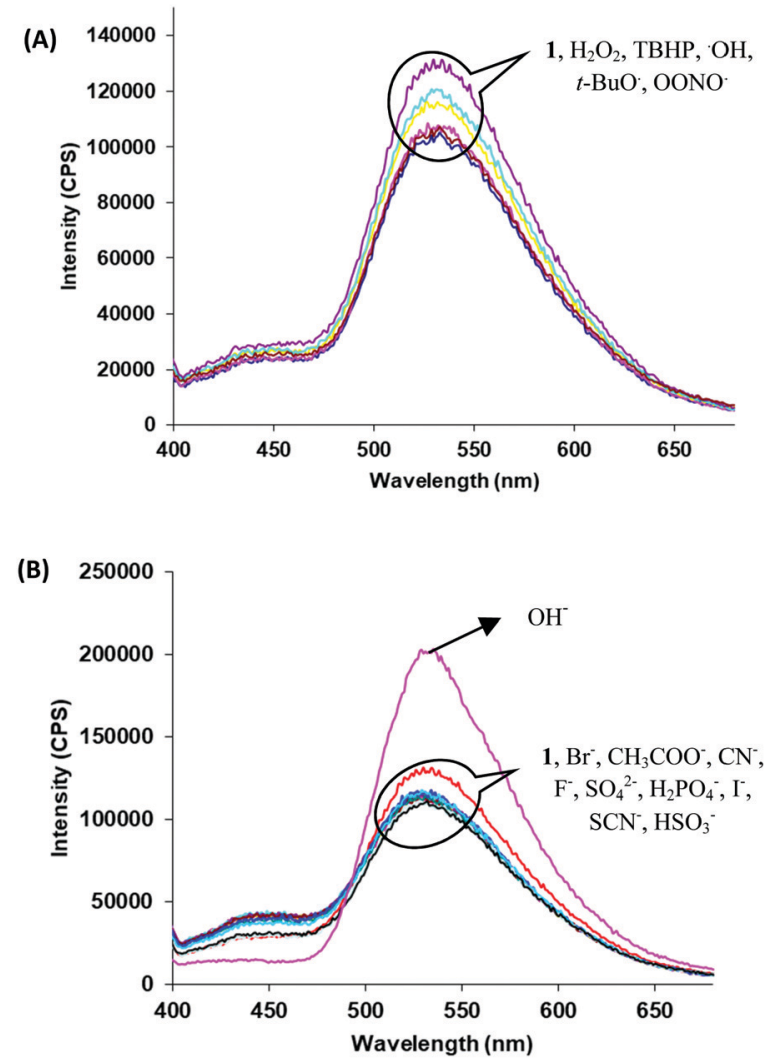

Fig. 2 Fluorescence spectra of probe 1 upon addition of (A) other ROS and (B) different anions in PBS/DMSO $(8 / 2, \mathrm{v} / \mathrm{v})$ mixture; $\lambda_{\mathrm{ex}}=350 \mathrm{~nm}$.

enhancement upon addition of hypochlorite at lower $\mathrm{pH}(5.5)$ as well at higher $\mathrm{pH}(8.5)$ and maximum emission enhancement was observed at a $\mathrm{pH}$ value of 7.5. These $\mathrm{pH}$ studies indicate that assemblies of probe 1 can detect hypochlorite under physiological conditions $(\mathrm{pH} \sim 7.4)$ and also in the $\mathrm{pH}$ range from 5.5 to 8.5 (Fig. S20, ESI $\dagger$ ). We also carried out absorption (Fig. S21, ESI $\dagger$ ) and fluorescence studies of probe 1 in the presence of various other $\mathrm{ROS}\left(\mathrm{H}_{2} \mathrm{O}_{2}\right.$, tert-butyl hydroperoxide (TBHP), $\mathrm{HO}^{\bullet}, t \mathrm{BuO}^{-}$, $\mathrm{OONO}^{-}$) (Fig. 2A) and other anions $\left(\mathrm{Br}^{-}, \mathrm{CH}_{3} \mathrm{COO}^{-}, \mathrm{OH}^{-}, \mathrm{CN}^{-}\right.$, $\mathrm{F}^{-}, \mathrm{SO}_{4}{ }^{2-}, \mathrm{H}_{2} \mathrm{PO}_{4}^{-}, \mathrm{I}^{-}, \mathrm{SCN}^{-}$, and $\mathrm{HSO}_{3}{ }^{-}$) (Fig. $2 \mathrm{~B}$ ), but no significant change in the fluorescence intensity was observed except with $\mathrm{OH}^{-}$which shows slight emission enhancement (1.2-fold).

To obtain insight into the sensing mechanism, we carried out ${ }^{1} \mathrm{H}$ NMR studies of probe 1 in the presence of sodium hypochlorite $(\mathrm{NaOCl}, 15.0 \mu \mathrm{M})$ ions in the $\mathrm{D}_{2} \mathrm{O}:$ DMSO- $_{6}(8: 2)$ mixture, and no signal corresponding to aldehyde proton was observed which clearly suggests that hydrolysis did not occur and hence, the imino linkages of probe $\mathbf{1}$ are stable in the presence of hypochlorite. Furthermore, the signals corresponding to hydroxyl protons at $11.13 \mathrm{ppm}$ and $\mathrm{N}-\mathrm{H}$ protons of azaindole units at $12.24 \mathrm{ppm}$ disappeared. All the signals corresponding to the aromatic protons of the phenol ring were shifted up-field (Fig. S22, ESI $\dagger$ ). No significant shift in the positions of protons of azaindole moieties was observed. On the basis of all these studies, we believe that hypochlorite addition led to the deprotonation of phenolic and $\mathrm{N}-\mathrm{H}$ protons, which suggests the interaction of hypochlorite with acidic protons (Fig. S23, ESI $\dagger$ ) (Scheme 1).

To understand the importance of the azaindole moiety further in probe $\mathbf{1}$, we synthesized derivatives $\mathbf{3}$ and $\mathbf{4}$ (Chart 1 and Scheme S1, ESI $\dagger$ ). Both the derivatives were found to be ESIPT-AIE active (Fig. S24 and S25, ESI $\dagger$ ) and exhibited similar photophysical changes in the presence of NaOCl (Fig. S26 and S27, ESI $\dagger$ ). Though derivatives 3 and 4 show similar responses towards hypochlorite, their detection limits were high and the detection process was slow. The high detection limit of derivative $3(0.62 \mu \mathrm{M})$ clearly highlights the role of $\mathrm{NH}$ groups of azaindole units in the generation of hypochlorite induced assemblies of deprotonated forms. On the other hand, the high detection limit $(0.25 \mu \mathrm{M})$ in the case of derivative 4 highlights the importance of the requirement of electron deficient azaindole units in comparison to electron rich moiety HPB on controlling the acidity of the phenolic group. These studies highlight the importance of the presence of indole moieties in the designed probe $\mathbf{1}$.

To understand the role of acidic protons/AIE phenomena in the sensing event, we also synthesized probe $5^{26}$ by coupling azaindole units with indolium moieties. The indolium based probe 5 exhibits aggregation caused quenching (ACQ) on increasing the water fraction (Fig. S28 and S29, ESI $\dagger$ ). The $\mathrm{p} K_{\mathrm{a}}$ value of the assemblies of probe 5 was found to be 6.85 (Fig. S30, ESI $\dagger$ ). Despite the high $\mathrm{p} K_{\mathrm{a}}$ value of the assemblies, sensitive and sharp photophysical changes were observed in the absorption as well as fluorescence studies in the presence of hypochlorite. In the absorption studies, a new absorption band appears at $490 \mathrm{~nm}$ and the intensity of the absorption band at $450 \mathrm{~nm}$ decreases along with the colour change from yellow to orange upon addition of hypochlorite (85 equiv.) in the PBS/ DMSO $(8 / 2, v / v)$ solvent mixture (Fig. S31, ESI $\dagger$ ). The fluorescence spectrum of probe $5(\phi=0.06)$ shows three-fold emission enhancement in the PBS/DMSO (8/2, v/v) solvent mixture upon addition of hypochlorite $(\phi=0.19)$ (Fig. S32, ESI $\dagger$ ).

We believe that upon deprotonation, the molecules of the as-deprotonated species are arranged in an ordered form to generate closely packed assemblies which are responsible for distinct absorption/emission changes. ${ }^{27}$ The detection limit of probe 5 for hypochlorite was found to be $38 \mu \mathrm{M}$. The sensing mechanism of probe 5 was also investigated by carrying out ${ }^{1} \mathrm{H}$ NMR studies in DMSO: $\mathrm{D}_{2} \mathrm{O}(2: 8)$ in the presence of sodium hypochlorite. The signal corresponding to $\mathrm{N}-\mathrm{H}$ disappears upon addition of hypochlorite and all the signals due to aromatic protons shift upfield. This hypochlorite induced deprotonation of $\mathrm{N}-\mathrm{H}$ proton (Fig. 3A) and upfield shifting of the aromatic protons indicate the enhanced $\pi-\pi$ intermolecular stacking of the molecules of probe 5 supporting our assumption on the formation of closely packed assemblies (Fig. 3B). Very interestingly, upon addition of TFA to the above mixture, the original spectrum was restored. These studies confirm the reversibility of the molecular recognition event in the presence of TFA. In comparison to probe 1, the detection limit is high and the weakly acidic nature of assemblies of probe $\mathbf{5}$ is the reason behind it. 


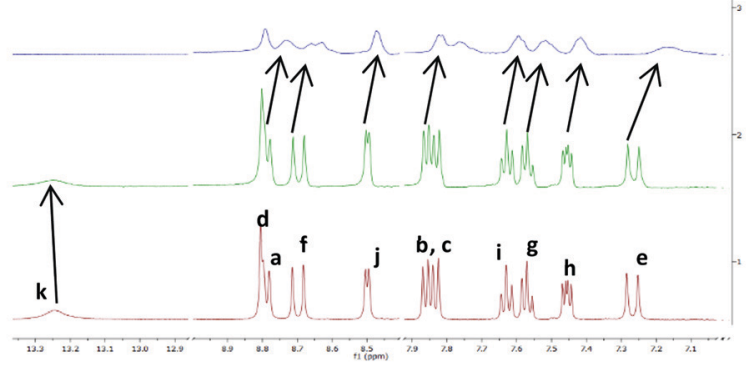

(B)

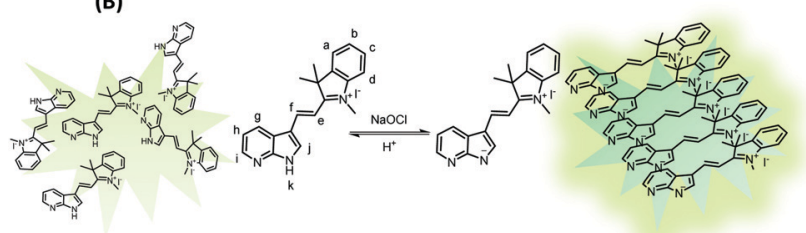

Fig. 3 (A) Overlay of ${ }^{1} \mathrm{HNMR}$ spectra of probe 5 in DMSO- $d_{6}$, DMSO- $d_{6}: \mathrm{D}_{2} \mathrm{O}$ and upon addition of $\mathrm{NaOCl}$. (B) Schematic representation of hypochlorite induced packing of molecules of probe 5 .

Furthermore, to explore the practical application of probe 1 for sensing of $\mathrm{ClO}^{-}$, we prepared 'dip strips' by loading the aggregated solution of probe $1\left(5.0 \mu \mathrm{M}\right.$, in $\left.\mathrm{H}_{2} \mathrm{O} / \mathrm{DMSO}, 8 / 2, \mathrm{v} / \mathrm{v}\right)$ on a pre-coated silica TLC plate. Probe 1 exhibits very weak yellow fluorescence in the absence of $\mathrm{ClO}^{-}$ions. Interestingly, upon applying solution of $\mathrm{ClO}^{-}$ions $\left(10^{-4}\right.$ to $\left.10^{-6} \mathrm{M}\right)$ on the strip an immediate concentration dependent emission change from light yellow to green was observed (Fig. S33, ESI $\dagger$ ). These results demonstrate the utilization of the coated strip for instant detection of hypochlorite up to $10^{-6} \mathrm{M}$ concentration. Furthermore, the role of assemblies of probe $\mathbf{1}$ as antioxidants in organic transformation was evaluated. Sodium hypochlorite is a known oxidant in organic transformation reactions. ${ }^{28}$ To examine the application of probe 1 to inhibit $\mathrm{NaOCl}$ induced oxidative coupling, we examined the oxidative coupling of benzylamine under standard conditions. In the control reaction under lab conditions, benzylamine was used as a reactant (Scheme S2, ESI $\dagger$ ). After the completion of the reaction (monitored by TLC) followed by usual workup and purification, the formation of product 7 was confirmed by ${ }^{1} \mathrm{H}$ NMR spectroscopic studies (Fig. S34, ESI $\dagger$ ). In the second reaction, we introduced probe 1 (50 $\mu$ l of $1 \mathrm{mM}$ solution) in the model reaction. Interestingly, the colour of the reaction mixture changed to yellow immediately and the ${ }^{1} \mathrm{H}$ NMR studies of the reaction mixture, after usual work up, showed the presence of reactant molecules only (Fig. S35, ESI $\dagger$ ). Thus, these results clearly demonstrate the potential of probe 1 to inhibit the $\mathrm{NaOCl}$ induced oxidation.

These studies motivated us to explore the utility of aggregates of probe $\mathbf{1}$ for the detection of hypochlorite in living cells and to further explore their potential as antioxidants for the protection of cells from hypochlorite induced death. We performed the studies on cancerous L-929 cell lines. The MTT (3-(4,5-dimethylthiazol2-yl)-2,5-diphenyltetrazoliumbromide) assay (to examine the
Probe 1 Only

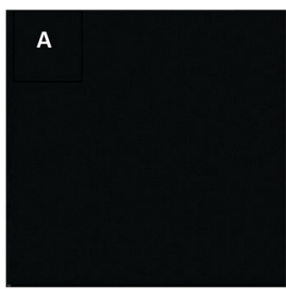

Probe 1

$+\mathrm{NaOCl}(5.0 \mu \mathrm{M})$

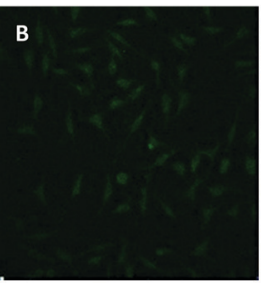

Probe 1 $+\mathrm{NaOCl}(10.0 \mu \mathrm{M})$
Fig. 4 Fluorescence images of L-929 cell lines in green channel treated (A) with probe 1 only $(2.0 \mu \mathrm{M})$ for $1 \mathrm{~h}$ min at $37^{\circ} \mathrm{C}$. (B) Fluorescence image of cells in the green channel upon treatment with probe 1 and $\mathrm{NaOCl}$ $(5.0 \mu \mathrm{M})$ for $30 \mathrm{~min}$ at $37^{\circ} \mathrm{C}$. (C) Fluorescence image of cells in the green channel upon treatment with probe 1 and then $\mathrm{NaOCl}(10.0 \mu \mathrm{M})$ for $30 \mathrm{~min}$ at $37{ }^{\circ} \mathrm{C}$. Fluorescence images are recorded at green $(510 \pm 20 \mathrm{~nm})$; $\lambda_{\text {ex }}=350 \mathrm{~nm}$.

cytotoxicity of probe 1 ) showed that $>86 \%$ of L-929 cells survived after $24 \mathrm{~h}$ in the presence of the probe $(15.0 \mu \mathrm{M})$ (Fig. S36, ESI $\dagger$ ). Thus, probe 1 was found to be non-toxic to the L-929 cells at lower concentration. The cells were incubated with probe $1(2.0 \mu \mathrm{M})$ in $10 \%$ fetal bovine serum (biological systems) and antibiotic (100 $\mathrm{U} \mathrm{ml}^{-1}$ penicillin, $100 \mu \mathrm{g} \mathrm{ml} \mathrm{m}^{-1}$ streptomycin) medium for $1 \mathrm{~h}$ at $37^{\circ} \mathrm{C}$. After that, the cells were washed with ice cold PBS three times to remove excess of probe 1 . The confocal microscopic image shows no intracellular fluorescence in the green channel which indicates that probe 1 is non-emissive in nature. The cells pre-treated with probe 1 were exposed to exogenous $\mathrm{ClO}^{-}(5.0 \mu \mathrm{M})$ ions for $30 \mathrm{~min}$ at $37{ }^{\circ} \mathrm{C}$ and washed with ice cold PBS. The cells exhibit fluorescence in the green channel which suggests that probe $\mathbf{1}$ is permeable through the cell membrane and acts as an effective imaging agent for hypochlorite with 'turn-on' green colored emission (Fig. 4). Next, we examined the ability of probe 1 to provide cytoprotection against exogenous hypochlorite. The L-929 cells were tested for cytotoxicity of sodium hypochlorite and MTT assay was used for the estimation of live cells. The control experiment shows $100 \%$ survival of the cells in the absence of sodium hypochlorite and probe 1 . The calculated $\mathrm{IC}_{50}$ of hypochlorite for L-929 cell lines was determined to be $45 \mu \mathrm{M}$ (Fig. S37, ESI $\dagger$ ). The cells pre-treated with different concentrations i.e. 50,25 and $12.5 \mu \mathrm{M}$ of probe 1 were exposed to exogenous $\mathrm{ClO}^{-}$ $(45 \mu \mathrm{M})$ ions for $30 \mathrm{~min}$ at $37{ }^{\circ} \mathrm{C}$. The cell viability was again recorded using MTT assay. The cells treated with $50 \mu \mathrm{M}$ of the probe shows a decrease in the percentage of live cells (38\%) due to the toxicity of the probe at high concentration. While at other concentrations i.e. $25 \mu \mathrm{M}$ and $12.5 \mu \mathrm{M}$ of probe 1 , the percentage of live cells was increased to $57 \%$ and $68 \%$, respectively (Fig. S38, ESI $\dagger$ ). These results show that probe 1 provides cytoprotection against exogenous hypochlorite.

\section{Conclusions}

The deprotonation-protonation strategy has been employed for reversible detection of hypochlorite by utilizing supramolecular assemblies of salicylaldehyde/indolium based probes in mixed 
aqueous media. Among the synthesized derivatives, assemblies of ESPIT-AIE active probe $\mathbf{1}$ having 'acidic protons' exhibit highly selective and sensitive responses towards hypochlorite. Interestingly, assemblies of indolium derivatives could detect hypochlorite in the micromolar range due to the generation of more ordered assemblies after the molecular recognition event. Thus, acidic strength along with the formation of ordered fluorescent assemblies post-molecular recognition event is an essential parameter for reversible hypochlorite recognition. Furthermore, the assemblies of probe $\mathbf{1}$ were successfully utilized for imaging hypochlorite in cells and as antioxidants to prevent hypochlorite induced cell death.

\section{Experimental}

\section{General experimental methods and materials ${ }^{29}$}

The general experimental methods, quantum yield calculations and materials used are the same as reported earlier by us. TEM images were recorded with a transmission electron microscope (TEM-JEOL 2100F).

\section{UV-vis and fluorescence titrations}

A $10^{-3} \mathrm{M}$ stock solution of derivative $\mathbf{1 / 2} / 3 / 4 / 5$ was prepared by dissolving 2.65/2.48/2.78/7.56/3.02 $\mathrm{mg}$ of compound in $10.0 \mathrm{ml}$ of DMSO; $15.0 \mu \mathrm{l}$ of the stock solution was further diluted with $2385 \mu \mathrm{l}$ of DMSO and $600 \mu \mathrm{l}$ of water/PBS buffer to prepare $3.0 \mathrm{ml}$ solution of derivatives $\mathbf{1} / \mathbf{2} / \mathbf{3} / \mathbf{4} / \mathbf{5}$ and this solution was used for each UV-vis and fluorescence experiment. The aliquots of freshly prepared standard solutions of anion $\left(\mathrm{Br}^{-}\right.$, $\mathrm{CH}_{3} \mathrm{COO}^{-}, \mathrm{CN}^{-}, \mathrm{OH}^{-}, \mathrm{F}^{-}, \mathrm{SO}_{4}{ }^{2-}, \mathrm{H}_{2} \mathrm{PO}_{4}{ }^{-}, \mathrm{I}^{-}, \mathrm{SCN}^{-}$, and $\mathrm{HSO}_{3}{ }^{-}$ as tetrabutylammonium salts) standard solution $\left(10^{-2} \mathrm{M}\right)$ in DMSO-water were added to $3.0 \mathrm{ml}$ solution of derivatives $\mathbf{1} / \mathbf{2} / \mathbf{3} / \mathbf{4} / \mathbf{5}$ taken in a quartz cuvette and spectra were recorded. Hypochlorite $\left(\mathrm{OCl}^{-}\right)$, hydrogen peroxide $\left(\mathrm{H}_{2} \mathrm{O}_{2}\right)$ and tert-butyl hydroperoxide (TBHP) were derived from 5\%, 30\% and 70\% aqueous solutions, respectively. Hydroxyl radicals $\left({ }^{\bullet} \mathrm{OH}\right)$ and tert-butoxy radicals $\left({ }^{\bullet} \mathrm{O} t \mathrm{Bu}\right)$ were generated by the reaction of $1.0 \mathrm{mM} \mathrm{Fe}^{2+}$ with $100 \mu \mathrm{M} \mathrm{H}_{2} \mathrm{O}_{2}$ or $100 \mu \mathrm{M}$ TBHP, respectively.

\section{Maintenance of $\mathbf{L}-929$ cell lines}

L-929 cells were cultured in Dulbecco's Modified Eagle Medium (HiMedia) supplemented with 10\% FBS (fetal bovine serum) and antibiotics (100 $\mathrm{U} \mathrm{ml}^{-1}$ penicillin, $100 \mu \mathrm{g} \mathrm{ml}^{-1}$ streptomycin) in a $\mathrm{CO}_{2}$ incubator at $37{ }^{\circ} \mathrm{C}, 5 \% \mathrm{CO}_{2}$ and $95 \%$ relative humidity in a tissue culture flask. The medium was changed on a regular basis and cells were harvested at the log phase of growth for various analysis.

\section{Confocal imaging ${ }^{30}$}

Confocal imaging was performed according to the reported method. L-929 cells (100000 cells per $\mathrm{ml}$ ) were incubated in 6 well plates having a coverslip in each well for $24 \mathrm{~h}$ and thereafter treated with different concentrations of probe 1 compound for 30 minutes. Cells were washed twice with chilled phosphate buffer saline (PBS) and then fixed with chilled $4 \%$ paraformaldehyde. Then washing of wells was carried out to remove the excessive dye. Finally, images were taken using a Nikon air laser scanning confocal microscope system.

\section{General procedure for synthesis of compound 1/2/3/4}

A solution of respective aldehyde and hydrazone (Scheme S1, ESI $\dagger$ ) in dry dichloromethane (DCM)/ethanol (EtOH) $(2: 8)$ was refluxed at $70{ }^{\circ} \mathrm{C}$ for $48 \mathrm{~h}$. After the completion of the reaction, precipitates were formed which were filtered and recrystallized from methanol to afford compounds $1 / 2 / 3 / 4$ in $85 \% / 80 \% / 80 \%$ / $70 \%$ yields.

\section{Characterization of compound 1}

Light yellow coloured solid; m.p.: $225{ }^{\circ} \mathrm{C} ;{ }^{1} \mathrm{H}$ NMR $(500 \mathrm{MHz}$, DMSO- $\left.d_{6}, \mathrm{ppm}\right) \delta=12.22(\mathrm{~s}, 1 \mathrm{H},-\mathrm{NH}), 11.11(\mathrm{~s}, 1 \mathrm{H},-\mathrm{OH}), 9.00$ $(\mathrm{s}, 1 \mathrm{H}, \mathrm{C}=\mathrm{NH}), 8.86(\mathrm{~s}, 1 \mathrm{H}, \mathrm{C}=\mathrm{NH}), 8.60-8.59(\mathrm{~m}, 1 \mathrm{H}, \mathrm{Ar}-\mathrm{H})$, 8.33 (d, $J=5 \mathrm{~Hz}, 1 \mathrm{H}, \mathrm{Ar}-\mathrm{H}), 8.05$ (s, $1 \mathrm{H}, \mathrm{Ar}-\mathrm{H}), 7.69$ (d, $J=5 \mathrm{~Hz}$, $1 \mathrm{H}, \mathrm{Ar}-\mathrm{H}), 7.39$ (t, $J=7.5 \mathrm{~Hz}, 1 \mathrm{H}, \mathrm{Ar}-\mathrm{H}), 7.24-7.22$ (m, 1H, Ar-H), 6.98-6.95 (m, 2H, Ar-H), ${ }^{13} \mathrm{C}$ NMR (DMSO- $\left.d_{6}, 125 \mathrm{MHz}, \mathrm{ppm}\right)$ $\delta=163.25,161.93,159.13,150.06,144.82,133.71,131.29$, 120.07, 118.69, 117.01; ESI/MS $\mathrm{m} / \mathrm{z}$ calculated 265.1089 , found 265.1156 [M+1] $]^{+}$(Fig. S39-S41, ESI $\dagger$ ).

\section{Characterization of compound 2}

Pale white solid; m.p.: $220{ }^{\circ} \mathrm{C} ;{ }^{1} \mathrm{H}$ NMR (500 MHz, DMSO- $d_{6}$, ppm) $\delta=12.23(\mathrm{~s}, 1 \mathrm{H}, \mathrm{N}-\mathrm{H}), 8.87(\mathrm{~s}, 1 \mathrm{H}, \mathrm{C}=\mathrm{NH}), 8.61(\mathrm{~s}, 1 \mathrm{H}, \mathrm{C}=\mathrm{NH})$, 8.59-8.58 (m, 1H, Ar-H), $8.33(\mathrm{~d}, J=5 \mathrm{~Hz}, 1 \mathrm{H}, \mathrm{Ar}-\mathrm{H}), 8.06$ (s, 1H, Ar-H), 7.86 (d, $J=5 \mathrm{~Hz}, 1 \mathrm{H}, \operatorname{Ar}-\mathrm{H}), 7.49(\mathrm{~m}, 1 \mathrm{H}$, Ar-H), 7.24-7.22 (m, 4H, Ar-H), ${ }^{13} \mathrm{C}$ NMR (DMSO- $d_{6}, 125 \mathrm{MHz}$, ppm) $\delta=164.83,159.87,133.55,132.67,119.84,117.36$, 117.25; ESI/MS $\mathrm{m} / \mathrm{z}$ calculated 248.1062, found 248.1093 [M] (Fig. S42-S44, ESI $\dagger$ ).

\section{Characterization of compound 3}

Pale yellow solid; m.p.: $120{ }^{\circ} \mathrm{C} ;{ }^{1} \mathrm{H}$ NMR (400 MHz, DMSO- $d_{6}$, ppm) $\delta=11.39(\mathrm{~s}, 1 \mathrm{H}), 8.76(\mathrm{~d}, J=12 \mathrm{~Hz}, 1 \mathrm{H}, \mathrm{Ar}-\mathrm{H}), 8.71(\mathrm{~s}, 1 \mathrm{H}$, $\mathrm{C}=\mathrm{NH}), 8.68(\mathrm{~d}, 1 \mathrm{H}, J=8 \mathrm{~Hz}, \mathrm{Ar}-\mathrm{H}), 8.44(\mathrm{~s}, 1 \mathrm{H}, \mathrm{C}=\mathrm{NH}), 7.61$ (s, 1H, Ar-H), $7.41-7.33$ (m, 3H, Ar-H), 7.04 (d, $J=12 \mathrm{~Hz}, 1 \mathrm{H}$, Ar-H), 6.96 (d, $1 \mathrm{H}, J=8 \mathrm{~Hz}, \mathrm{Ar}-\mathrm{H}), 3.95\left(\mathrm{~s}, 3 \mathrm{H}, \mathrm{CH}_{3}\right),{ }^{13} \mathrm{C} \mathrm{NMR}$ $\left(\mathrm{DMSO}-d_{6}, 100 \mathrm{MHz}, \mathrm{ppm}\right) \delta=161.41,158.12,150.24$, $144.55,134.98,132.88,131.12$, 119.02, 117.80, 110.49, 42.52; ESI/MS $m / z$ calculated 301.1065 , found $301.1245[\mathrm{M}+\mathrm{Na}]^{+}$ (Fig. S46-S48, ESI $\dagger$ ).

\section{Characterization of compound 4}

Pale yellow solid; m.p.: $>250{ }^{\circ} \mathrm{C}$; ${ }^{1} \mathrm{H}$ NMR (500 MHz, DMSO- $d_{6}$, ppm) $\delta=11.28(\mathrm{~s}, 1 \mathrm{H}), 8.93(\mathrm{~s}, 1 \mathrm{H}, \mathrm{C}=\mathrm{NH}), 8.77(\mathrm{~s}, 1 \mathrm{H}, \mathrm{C}=\mathrm{NH})$, $7.85(\mathrm{~d}, 4 \mathrm{H}, J=5 \mathrm{~Hz}, \operatorname{Ar}-\mathrm{H}), 7.65(\mathrm{~d}, 4 \mathrm{H}, J=5 \mathrm{~Hz}$, Ar-H), 7.40-7.36 (m, 2H, Ar-H), 7.30 (d, J = $10 \mathrm{~Hz}, 2 \mathrm{H}, \mathrm{Ar}-\mathrm{H})$, 6.99-6.81 (m, 25H, Ar-H), ${ }^{13} \mathrm{C}$ NMR $\left(\mathrm{CDCl}_{3}, 125 \mathrm{MHz}, \mathrm{ppm}\right)$ $\delta=164.86,162.07,159.86,143.97,140.53,140.32,136.29$, 133.46, 132.91, 132.36, 132.04, 131.43, 128.99, 127.09, 126.60, 125.18, 119.50, 117.74, 117.01; ESI/MS $m / z$ calculated 757.3219, found $757.7424[\mathrm{M}+1]^{+}$(Fig. S52-S54, ESI $\dagger$ ). 


\section{Conflicts of interest}

There are no conflicts to declare.

\section{Acknowledgements}

M. K. is thankful to SERB (Ref. No. EMR/2016/003473) and CSIR (Ref. no.: 02(0266)/16/EMR-II) and V. B. is thankful to RUSA 2.0 for financial support. G. S. is thankful to CSIR (New Delhi) for Senior Research Fellowship (SRF) and A. K. is thankful to DST (New Delhi) for INSPIRE fellowship.

\section{Notes and references}

1 X. Chen, F. Wang, J. Y. Hyun, T. Wei, J. Qiang, X. Ren, I. Shin and J. Yoon, Chem. Soc. Rev., 2016, 45, 2976.

2 T. Chen, Y. Hu, Y. Cen, X. Chu and Y. Lu, J. Am. Chem. Soc., 2013, 135, 11595.

3 M. Phillipson and P. Kubes, The Neutrophil in Vascular Inflammation, Nat. Med., 2011, 17, 1381.

4 C. Zhang, L. Zhang, W. Wu, F. Gao, R.-Q. Li, W. Song, Z.-N. Zhuang, C.-J. Liu and X.-Z. Zhang, Adv. Mater., 2019, 31, 1901179.

5 R. J. Goiffon, S. C. Martinez and D. Piwnica-Worms, Nat. Commun., 2015, 6, 6271.

6 C. Chang, F. Wang, J. Qiang, Z. Zhang, Y. Chen, W. Zhang, Y. Wang and X. Chen, Sens. Actuators, B, 2017, 243, 22.

7 P. Chen, Z. Zheng, Y. Zhu, Y. Dong, F. Wang and G. Liang, Anal. Chem., 2017, 89, 5693.

8 B. Pan, H. Ren, X. Lv, Y. Zhao, B. Yu, Y. He, Y. Ma, C. Niu, J. Kong, F. Yu, W. Sun, Y. Zhang, B. Willard and L. Zheng, J. Transl. Med., 2012, 10, 65.

9 J.-S. Lan, L. Liu, R.-F. Zeng, Y.-H. Qin, Y. Liu, X.-Y. Jiang, A. Aihemaiti, Y. Ding, T. Zhang and R. J. Y. Ho, Chem. Commun., 2020, 56, 1219.

10 K. Kumar, S. Kaur, S. Kaur, G. Bhargava, S. Kumar and P. Singh, J. Mater. Chem. B, 2020, 8, 125.

11 J.-T. Hou, H. S. Kim, C. Duan, M. S. Ji, S. Wang, L. Zeng, W. X. Ren and J. S. Kim, Chem. Commun., 2019, 55, 2533.
12 L. Wu, Q. Yang, L. Liu, A. C. Sedgwick, A. J. Cresswell, S. D. Bull, C. Huang and T. D. James, Chem. Commun., 2018, 54,8522 .

13 X. Zhong, Q. Yang, Y. Chen, Y. Jiang, B. Wang and J. Shen, J. Mater. Chem. B, 2019, 7, 7332.

14 X. Zhang, W. Zhao, B. Li, W. Li, C. Zhang, X. Hou, J. Jiang and Y. Dong, Chem. Sci., 2018, 9, 8207.

15 M.-Y. Li, K. Li, Y.-H. Liu, H. Zhang, K.-K. Yu, X. Liu and X. Yu, Anal. Chem., 2020, 92, 3262.

16 M. Ren, Z. Li, J. Nie, L. Wang and W. Lin, Chem. Commun., 2018, 54, 9238.

17 L. Long, Y. Han, W. Liu, Q. Chen, D. Yin, L. Li, F. Yuan, Z. Han, A. Gong and K. Wang, Anal. Chem., 2020, 92, 6072.

18 D. Wu, L. Chen, Q. Xu, X. Chen and J. Yoon, Acc. Chem. Res., 2019, 52, 2158.

19 B. Huo, M. Du, A. Shen, M. Li, Y. Lai, X. Bai, A. Gong, L. Fang and Y. Yang, Sens. Actuators, B, 2019, 284, 23.

20 S. T. Manjare, J. Kim, Y. Lee and D. G. Churchill, Org. Lett., 2014, 16, 520.

21 B. Wang, P. Li, F. Yu, P. Song, X. Sun, S. Yang, Z. Lou and K. Han, Chem. Commun., 2013, 49, 1014.

22 F. Liu, Y. Gao, J. Wang and S. Sun, Analyst, 2014, 139, 3324.

23 S. I. Reja, V. Bhalla, A. Sharma, G. Kaur and M. Kumar, Chem. Commun., 2014, 50, 11911.

24 M. J. Celestine, L. S. Joseph and A. A. Holdera, Inorg. Chim. Acta, 2017, 454, 254.

25 N. Karton-Lifshin, L. Albertazzi, M. Bendikov, P. S. Baran and D. Shabat, J. Am. Chem. Soc., 2012, 134, 20412.

26 H. Deol, M. Kumar and V. Bhalla, RSC Adv., 2018, 8, 31237.

27 H. Tong, Y. Hong, Y. Dong, M. Häußler, J. W. Y. Lam, Z. Li, Z. Guo, Z. Guo and B. Z. Tang, Chem. Commun., 2006, 3705.

28 G. F. P. de Souza, T. W. von Zuben and A. G. Salles Jr, ACS Sustainable Chem. Eng., 2017, 5, 8439.

29 S. Pramanik, V. Bhalla and M. Kumar, ACS Appl. Mater. Interfaces, 2014, 6, 5930.

30 M. V. Berridge, P. M. Herst and A. S. Tan, Annu. Rev., 2005, 11, 127. 